\title{
Heavy Metals Pollution and Ecological Risk Assessment in Surface Sediments of West Coast of Peninsular Malaysia
}

\author{
Tijjani Rufa'i Buhari and Ahmad Ismail
}

\begin{abstract}
In this study, Surface sediments from six sampling sites in the west coast of Peninsular Malaysia were analysed for heavy metals $(\mathrm{Cu}, \mathrm{Zn}, \mathrm{Pb}, \mathrm{Cd}$ and $\mathrm{Ni})$ to evaluate the pollution status and ecological risk assessment. Sediment samples were collected in triplicates from six sampling sites in the study area. Direct aqua - regia method was employed to analyse the total metal concentrations in the sediment samples. The filtrates obtained from the sediments, were determined for heavy metals by using an air -air acetylene flame atomic absorption spectrophotometer (AAS) Perkin Elmer Analyst 800. The results showed that $\mathrm{Zn}$ and $\mathrm{Cd}$ reveal considerable contamination, and almost all the sampling sites were of moderate degree of contamination. The calculated; Potential Ecological Risk Index (RI) ranged from low to moderate, the Sediment Quality Guideline Quotient (SQG-Q), for all the sampling sites falls into impact level category 2; indicating moderate impact potential for observing adverse biological effects. All the studied metals except $\mathrm{Zn}$ were found below effective range-median (ERM). The present study reveals that surface sediments from west coast of Peninsular Malaysia were exposed to heavy metals pollution; $\mathrm{Zn}$ and $\mathrm{Cd}$ were observed as metals of Ecotoxicological significant in the present study.
\end{abstract}

Index Terms-Surface sediments, heavy metals, pollution, ecological risk, west coast of Peninsular Malaysia.

\section{INTRODUCTION}

The concentrations of heavy metals in surface sediments of west coast of Peninsular Malaysia has been studied extensively and were reported in previous studies by many authors [1]-[4]. Results from these studies have revealed elevated levels of $\mathrm{Cu}, \mathrm{Zn}, \mathrm{Pb}$ and $\mathrm{Cd}$ in the study areas. Coastal and estuarine regions are the important sinks for many persistent pollutants and they accumulate in the organisms and bottom sediments [5]. Pollution of aquatic ecosystems by heavy metals is an important environmental problem [6] because of its permanent disturbances in marine ecosystems, leading to environmental and ecological degradation [7].

Heavy metals are accumulated in marine sediments, where they are incorporated in several biological and chemical cycles, affecting the water column and biota. Anthropogenic

Manuscript received July 24, 2015; revised December 28, 2015. This work was supported in part by funding from the Ministry for Higher Education Malaysia under Fundamental Research Grant Scheme (Vot: 5523641).

Tijjani Rufa'i Buhari is with the Department of Biological Sciences Northwest University, Kano, Nigeria (e-mail: trbuhari@yahoo.com).

Ahmad Isma'il is with the Department of Biology, Faculty of Science, Universiti Putra Malaysia, 43300 Serdang, Selangor, Malaysia (e-mail: aismail@science.upm.edu.my). impacts including; industrial discharges, domestic sewage, non-point source, runoff and atmospheric precipitation are the main sources of toxic heavy metals that enter aquatic ecosystems [8], [9]. Studies conducted by Ismail and Ramli [2], Morton and Blackmore [10] and Ip et al. [11] have shown that trace metal pollution occurs in sediments from coastal areas which are near actively operated industries, urban centers and agriculture [2], [10] and [11]. Yap and Chew [12] have also reported significant higher concentration of metal in sediments collected from active urban area potentially receiving domestic wastes and vehicular runoff in Peninsular Malaysia [12].

Coastal pollution has been increasing significantly over the recent years and is found compounding environmental problems in many developing countries [13]. Elevated levels of heavy metals were reported from the sediments of Straits of Johore [14] and Straits of Malacca [4] in Peninsular Malaysia that indicates anthropogenic in put in these areas. As in many developing countries, Malaysian coastal zone has experienced severe deterioration as a result of pollution. Many researches concerning heavy metals concentrations in the surface sediments of west coast Peninsular Malaysia were reported by [4], [15], [16], but there is a gap with regards to heavy metals toxicity and ecological risks implications in this area.

The objectives of the present study were: 1 - to determine the concentration and distribution of heavy metals in the surface sediments of west coast of Peninsular Malaysia and 2to evaluate the studied metals toxicity and their ecological risks implications.

\section{Materials AND Methods}

Samplings were conducted in August 2008 to June 2010. A total of six sampling sites were selected for surface sediments in the west coast of Peninsular Malaysia (Fig. 1). The coordinates of sampling sites were recorded with Global positioning system (Garmin OREGON 45OT 850MB waterproof GPS). Description of each sampling site was given in Table I. Top 3-5 cm surface sediments [4] and [17] were collected in triplicates from three different points within a certain area (approximately 1 meter radius) from each sampling site using plastic scoop and placed in separate labelled polyethylene plastic bags. Each sediment sample was instantly placed in ice and transported to the laboratory until further analysis.

Sediment samples were dried in the laboratory using an air-circulating oven to a constant dry weight at $80^{\circ} \mathrm{C}$. The 
dried sediment samples were crushed to powder by using a porcelain mortar and pestle then sieved vigorously to produce homogeneity [17], through a $63 \mu \mathrm{m}$ stainless steel aperture sieve. For analyses of total heavy metals concentrations $(\mathrm{Cu}$, $\mathrm{Zn}, \mathrm{Pb}, \mathrm{Cd}$ and $\mathrm{Ni}$ ) in the sediment sample, direct aqua-regia method was employed as described by Ismail [17].
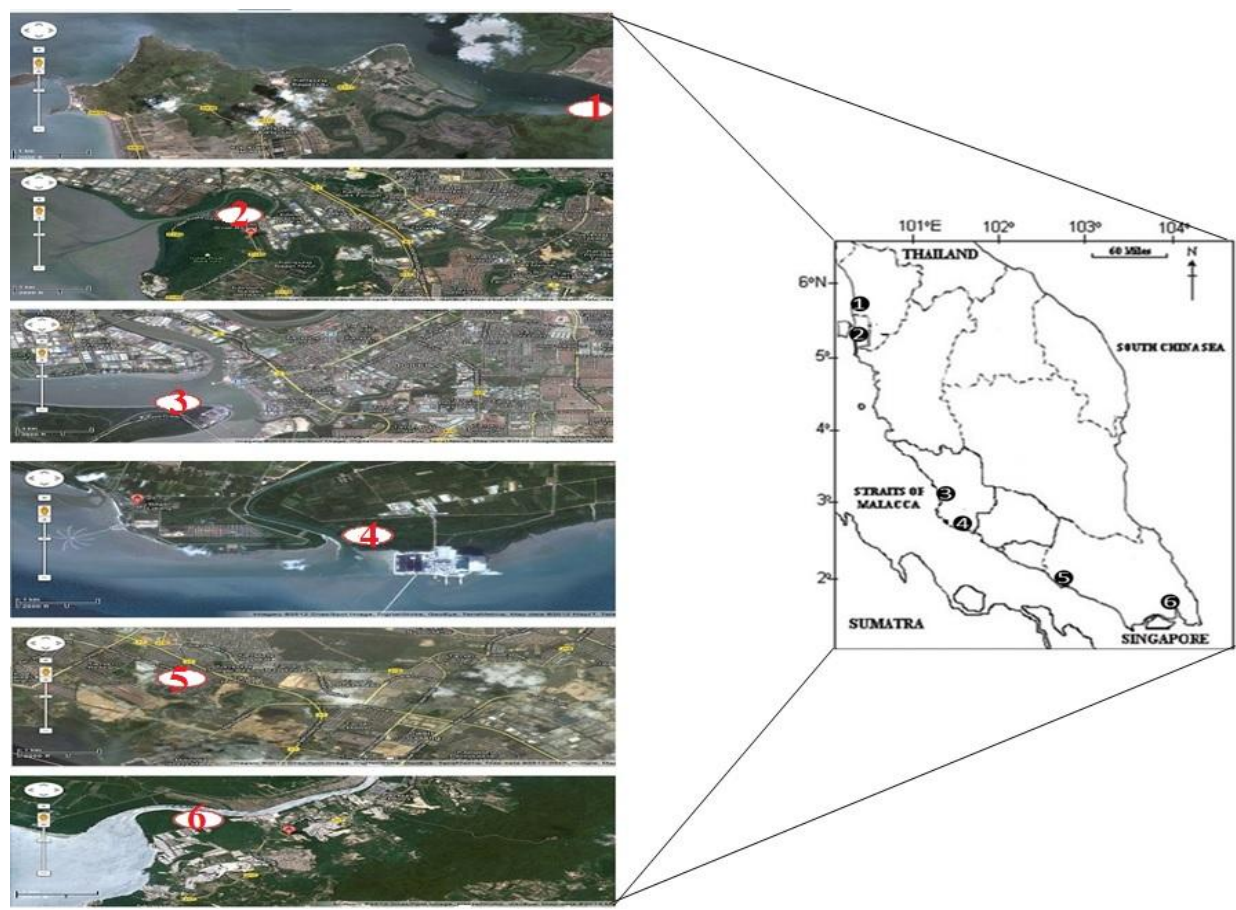

Fig. 1. Map of west coast of Peninsular Malaysia showing sampling sites: 1, 2, 3, 4, 5 and 6.

TABLE I: DESCRIPTION OF SAMPLING SITES IN THE WEST COAST OF PENINSULAR MALAYSIA

\begin{tabular}{|c|c|c|c|}
\hline $\mathrm{S} / \mathrm{No}$ & Sampling site & Coordinates & Site description \\
\hline 1. & Sengantang Garam, Kedah & 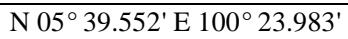 & Jetty, aqua cultural area and paddy field \\
\hline 2. & Kuala Juru, Penang & $\mathrm{N} 05^{\circ} 19.683^{\prime} \mathrm{E} 100^{\circ} 22.949^{\prime}$ & Industrial area \\
\hline 3. & Sungai Puluh, Klang & $\mathrm{N} 03^{\circ} 04.786^{\prime} \mathrm{E} 101^{\circ} 23.903^{\prime}$ & $\begin{array}{l}\text { Jetty receiving domestic wastes and industrial } \\
\text { area }\end{array}$ \\
\hline 4. & BaganLalang, Selangor & $\mathrm{N} 02^{\circ} 36.669^{\prime} \mathrm{E} 101^{\circ} 41.100^{\prime}$ & Recreational and agricultural areas \\
\hline 5. & Minyak Beku, Johor & 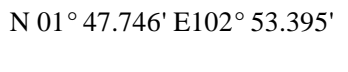 & $\begin{array}{l}\text { Jetty receiving domestic wastes and shipping } \\
\text { activities }\end{array}$ \\
\hline 6. & Sungai Tiga, Johor & $\mathrm{N} 01^{\circ} 25.841^{\prime} \mathrm{E} 104^{\circ} 00.281^{\prime}$ & Jetty, agricultural and oil plantation \\
\hline
\end{tabular}

About 0.5-1.0 $\mathrm{g}$ of each dried sediment sample was weighed and digested in a combination of concentrated nitric acid (AnalaR grade, BDH 69\%) and per chloric acid (AnalaR $\mathrm{BDH} 60 \%)$ in the ratio of $4: 1$, first at low temperature $\left(40^{\circ} \mathrm{C}\right)$ for 1 hour and then increased to $140^{\circ} \mathrm{C}$ for at least 3 hours [17] Later, the digested samples were diluted to $40 \mathrm{~mL}$ with double distilled water. After filtration, the prepared samples were determined for $\mathrm{Cu}, \mathrm{Zn}, \mathrm{Pb}, \mathrm{Cd}$ and $\mathrm{Ni}$ using an air-acetylene flame Atomic Absorption Spectrophotometer (AAS) PerkinElmer Model AAnalyst 800. The data were presented in $\mu \mathrm{g} / \mathrm{g}$ dry weight.

During the period of AAS metal analysis, a quality control sample was routinely included for every 5-10 samples. Procedural blanks and quality control samples made from standard solutions for $\mathrm{Cu}, \mathrm{Zn}, \mathrm{Pb}, \mathrm{Cd}$ and $\mathrm{Ni}$ were analyzed after every 5-10 samples to ensure the sensitivity and recovery of the instrument used. The procedures of quality assurance (QA) and quality control (QC) were employed to ensure the validity of the analytical data [18]. All plastics and glassware used were washed with detergent, Deacon 90, rinsed with double-distilled water and soaked in $10 \% \mathrm{HNO} 3$ for at least $24 \mathrm{~h}$, then rinsed with double-distilled water and allowed to dry at room temperature. The QA and QC were controlled by procedural blanks, sample replicates and certified reference material (CRM). The quality of the method was checked with a certified reference material (CRM) for Soil from International Atomic Energy Agency (IAEA), Soil-5, Vienna; Austria and Dogfish liver DOLT-3 from National Research Council Canada (NRCC) were analysed. These were checked to accuracy of the digestion method with the certified values supplied by the IAEA and NRCC. To ensure the sensitivity of the Atomic Absorption Spectrophotometer (AAS) and generate calibration curves against which sample concentrations were calculated. The results of similar digested samples analyzed for $\mathrm{Cu}, \mathrm{Zn}, \mathrm{Pb}, \mathrm{Cd}$ and $\mathrm{Ni}$ by the flame AAS Perkin Elmer A Analyst 800 showed acceptable recoveries of the metals. About $94-107 \%$ for soil and $87-110$ for dogfish liver, recoveries of these metals were listed in Table II. The percentages of recoveries for the heavy metal analyses were 97 - 107 (Table II).

All statistical analyses of data were carried out using SPSS statistical package programs version 17 and graphs were plotted with Microsoft EXCEL 2007. Data were tested for the basic assumptions of normality and homogeneity of variance in exploratory data analysis in SPSS 17.

The assessment of sediment contamination was performed based on Hakanson's procedures [19]; the contamination factor is the ratio between the mean concentration of single 
metal in the surface sediment and the background level as a general reference and could be calculated from the equation as:

$$
\text { Cif }=C i / C i n
$$

where $C i$ is the mean concentration of an individual metal examined and $\mathrm{Cin}$ is the baseline or background value of the individual metal. Lowest metals concentrations in sediment from the sampling sites were used as background value in this study.

TABLE II: COMPARISON OF ANALYTICAL RESULT OF CRM SOIL-5 AND DOLT-3 WITH CERTIFIED CONCENTRATIONS USING AAS PERKIN ELMER A

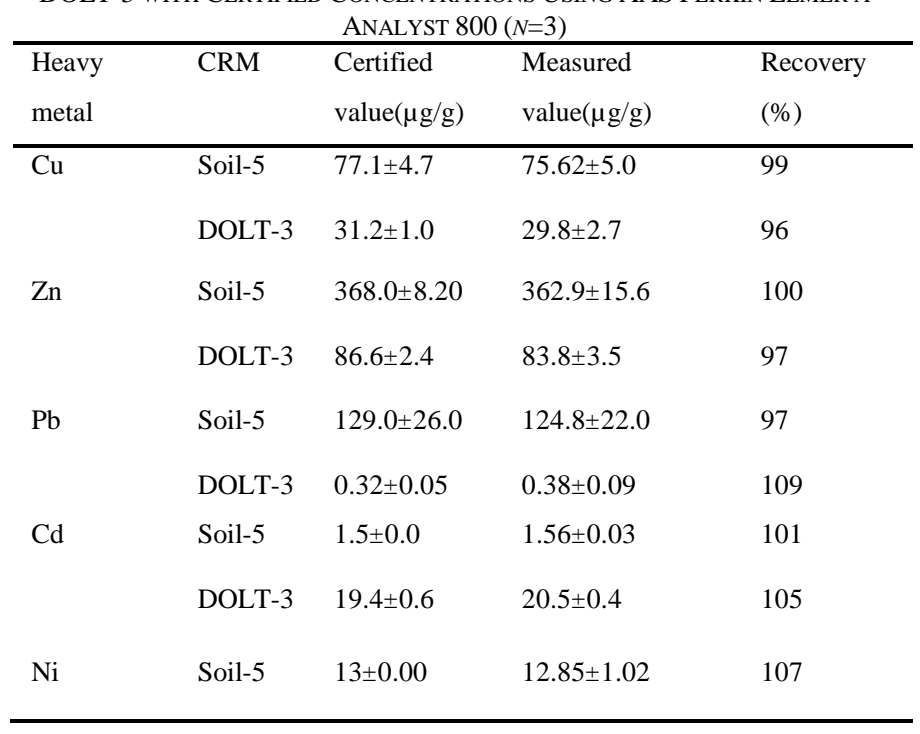

Cif is defined according to the following categories: Cif $<1$ low contamination factor; $1 \leq C$ if $<3$ moderate contamination factor; $3 \leq$ Cif $<6$ considerable contamination factors; Cif $\geq 6$ very high contamination factor.

Degree of contamination $(C d)$ is defined as the sum of contamination factors for all metals in the surface sediments: $C d=($ Cif $)$

The following terminologies were used to describe the degree of contamination: $C d<7$ low degree of contamination; $7 \leq C d<14$ moderate degree of contamination; $14 \leq C d<28$ considerable degree of contamination; $C d \geq$ very high degree of contamination.

Potential ecological risk index (RI) was introduced originally by Hakanson [19], to assess the degree of heavy metal pollution in sediment, according to the toxicity of heavy metals and the response of the environment:

$$
R I=\Sigma E r i
$$

$R I$ is the potential ecological risk index for all the heavy metals in the sediments, which is the sum of $\operatorname{Er} i$.

$$
\text { Er } i=\operatorname{Tr} i C f i
$$

where: $\operatorname{Er} i$ is the potential ecological risk index of an individual metal, $\operatorname{Tr} i$ is the metal toxic response factor given by Hakanson [19] as $(\mathrm{Zn}=1, P b=C u=N i=5, C d=30) C f i$ is the metal pollution factor.

$$
C i f=C i / C i n
$$

where: $C i$ is the concentration of metals in the sediment, and $\mathrm{Cin}$ is the background value of metals in the sediments. Hakanson [19] has defined five and four categories of Er $i$ and $R I$ respectively and was used by Wu et al. [20] as shown in

\begin{tabular}{|c|c|c|c|}
\hline Eri & Risk grade & $R I$ & Risk grade \\
\hline$<40$ & $\begin{array}{l}\text { Low potential } \\
\text { ecological risk }\end{array}$ & $<150$ & $\begin{array}{l}\text { Low potential } \\
\text { ecological risk }\end{array}$ \\
\hline $40-80$ & $\begin{array}{l}\text { Moderate potential } \\
\text { ecological risk }\end{array}$ & $150-300$ & $\begin{array}{l}\text { Moderate } \\
\text { potential } \\
\text { ecological risk }\end{array}$ \\
\hline $80-160$ & $\begin{array}{l}\text { Considerable potential } \\
\text { ecological risk }\end{array}$ & $300-600$ & $\begin{array}{l}\text { High potential } \\
\text { ecological risk }\end{array}$ \\
\hline $160-320$ & $\begin{array}{l}\text { High potential } \\
\text { ecological risk }\end{array}$ & $\geq 600$ & $\begin{array}{l}\text { Significantly high } \\
\text { potential } \\
\text { ecological risk }\end{array}$ \\
\hline$\geq 320$ & $\begin{array}{l}\text { Significantly high } \\
\text { potential ecological } \\
\text { risk }\end{array}$ & & \\
\hline
\end{tabular}
Table III.

TABLE III: RISK GRADES INDICES AND GRADES OF POTENTIAL ECOLOGICAL RisK OF HEAVY METAL POLLUTION [20]

Mean Sediment Quality Guidelines - Quotient (SQG-Q) is an index that works as a central tendency indicator of adverse biological effects due to mixture of chemicals in different concentrations. The Mean SQG-quotient was calculated for each sampling site, using the following equations [21]:

$$
\begin{gathered}
S Q G-Q=\Sigma n i=1 P E L-Q / n \\
P E L-Q=C / P E L
\end{gathered}
$$

where: $P E L-Q$ is probable effect level quotient, $C$ is heavy metal concentration at each sampling site, PEL is probable effect level of each heavy metal and $\mathrm{n}$ is the number of heavy metals or contaminant used. The $P E L$ values used in this study were: $C u=108, Z n=271, P b=112, C d=4.21$ and $N i=42.1$ [22].

According to MacDonald et al. [23] each sampling site can be assigned to one of the following impact level categories:

Category 1: $S Q G-Q \leq 0.1$ unimpacted: lowest potential for observing adverse biological effects; Category 2: $0.1<$ $S Q G-Q<1$ : moderate impact potential for observing adverse biological effects; Category 3: $S Q G-Q \geq 1$ : highly impacted potential for observing adverse biological effects.

Sediment Quality Guidelines (SQG) of effect range-low (ERL) and effect range-median (ERM) derived from the database of Long et al. [24] (Table III) was used to assess the level of toxicity of heavy metals in the surface sediments.

Metal concentrations below the ERL value, indicates effects on biota would rarely be observed, concentrations equal to the ERL but below the ERM, biota could occasionally be affected by the pollutant, whereas at concentrations equal to or above the ERM, effects would be expected to occur frequently.

\section{RESULTS AND CONCLUSION}

\section{A. Heavy Metal Concentrations in the Surface Sediment}

The mean concentration and standard error (SE) of heavy metals in the surface sediments from six sampling sites in the west coast of Peninsular Malaysia were presented in Table IV. The mean range total concentrations of $\mathrm{Cu}, \mathrm{Zn}, \mathrm{Pb}, \mathrm{Cd}$ and $\mathrm{Ni}$ 
in the surface sediment from the six sites ranged from 12.79 $65.39,60.83$ - 442.19, 8.46 - 53.73, 0.60 - 1.65 and 10.09 $29.25 \mu \mathrm{g} / \mathrm{g}$ dry weight, respectively. Statistical analysis showed that the metal concentrations of $\mathrm{Cu}, \mathrm{Zn}, \mathrm{Pb}, \mathrm{Cd}$ and $\mathrm{Ni}$ were significantly different $(p<0.05)$ between the sampling sites.

Average shale was used as reference baseline in this study to provide elemental background concentration. The concentration of $\mathrm{Cu}$ at Site 2 was higher than the reference baseline of average shale. The concentrations of $\mathrm{Zn}, \mathrm{Cd}$ and $\mathrm{Pb}$ were above the reference baseline of average shale except $\mathrm{Pb}$ at Site 4 . High metal concentrations might suggest metals contamination in the area. The total concentrations of Ni were found below the average shale baseline value suggesting low concentration of this metal expected to pose contamination.

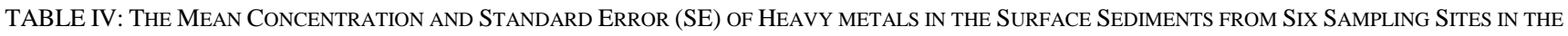
WEST COAST OF PENINSULAR MALAYSIA

\begin{tabular}{|c|c|c|c|c|c|}
\hline Sampling site & $\mathrm{Cu}$ & $\mathrm{Zn}$ & $\mathrm{Pb}$ & $\mathrm{Cd}$ & $\mathrm{Ni}$ \\
\hline 1 & $34.79 \pm 0.19$ & $60.83 \pm 1.74$ & $27.78 \pm 1.41$ & $1.25 \pm 0.04$ & $13.11 \pm 0.16$ \\
\hline 2 & $65.39 \pm 0.70$ & $442.19 \pm 4.13$ & $29.97 \pm 0.36$ & $1.24 \pm 0.08$ & $29.25 \pm 0.08$ \\
\hline 3 & $35.48 \pm 0.64$ & $256.50 \pm 2.40$ & $34.22 \pm 0.23$ & $1.37 \pm 0.06$ & $26.42 \pm 0.24$ \\
\hline 4 & $12.79 \pm 0.57$ & $75.38 \pm 1.63$ & $8.46 \pm 0.83$ & $0.60 \pm 0.05$ & $10.09 \pm 0.54$ \\
\hline 5 & $37.64 \pm 0.95$ & $241.87 \pm 0.78$ & $53.73 \pm 0.18$ & $1.65 \pm 0.11$ & $21.18 \pm 0.48$ \\
\hline 6 & $13.90 \pm 0.03$ & $117.38 \pm 0.99$ & $28.28 \pm 0.11$ & $1.40 \pm 0.14$ & $11.89 \pm 0.29$ \\
\hline Non-polluted ${ }^{\text {a }}$ & $<25$ & $<90$ & $<40$ & - & $<20$ \\
\hline Moderately polluted $^{\text {a }}$ & $25-50$ & $90-200$ & $40-60$ & - & $20-50$ \\
\hline Heavily polluted ${ }^{a}$ & $>50$ & $>200$ & $>60$ & $>6$ & $>50$ \\
\hline Average Shale ${ }^{b}$ & 45 & 95 & 20 & 0.30 & 68 \\
\hline $\mathrm{ERL}^{\mathrm{c}}$ & 34 & 150 & 46.7 & 1.2 & 20.9 \\
\hline $\mathrm{ERM}^{\mathrm{c}}$ & 270 & 410 & 218 & 9.6 & 51.6 \\
\hline
\end{tabular}

${ }^{\mathrm{a}}$ US EPA [25]

${ }^{\mathrm{b}}$ World average Shale [26]

${ }^{\mathrm{c}}$ [24]

It was observed that the concentration of $\mathrm{Cu}, \mathrm{Zn}$ and $\mathrm{Ni}$ were found higher at Site 2 than those at other sampling sites, indicating that the site is comparatively more polluted with these metals compared to other sampling sites. This might be attributed to different industries located at Prai Industrial area. In addition to discharge from Prai industrial area, domestic, agricultural and fishing activities might contribute the higher metals concentration at this Site. These industries discharged their effluents into the Juru River and the canals, which finally drain into the sea through a pump house [27]. The industries operating in the area as reported by [28] include: electronics; textiles; basic and fabricated metal products; food processing and canning; processing of agricultural products; feed mills; chemical plants; rubber based industry; timber based wood products; paper products and printing works; and transport equipment. It has been reported by Alkarkhi et al. [28] that sediments from this area were highly polluted with $\mathrm{Fe}, \mathrm{Zn}$ and $\mathrm{Cd}$. Arsenic, Cr, Cd, Zn, Cu, Hg, phosphate, ammonia, nitrate, sulphates, chloride and aluminium were also discharged as contaminants from these industries and other activities [29] Other main activities include ships' harbour with petroleum unloading and a red earth quarry, which extends right up to the coastline. In addition to these, some fishing villages situated in the area also contributed to the high anthropogenic input of heavy metals through Juru River, Semilang River and Jejawi River. Domestic sewage effluents were found as an important source of trace metals in previous studies [30], [31].

$\mathrm{Pb}$ and $\mathrm{Cd}$ concentrations were observed highest at Site 5, might be attributed to the anthropogenic input from domestic and jetty near the sampling site. In addition, Strait of Malacca and Batu Pahat Minyak Beku Ferry Terminal operating between the Peninsular Malaysia and the Indonesia also contributed high metals concentration to the sampling site. In general, the higher concentrations of metals at Site 2 and 5 could be explained by the proximity of these sites to high source of anthropogenic inputs from domestics, shipping and industrial area. Zhou et al. [32] has reported that sediments collected from Fo Tan in Hong Kong were mostly polluted by $\mathrm{Cu}, \mathrm{Zn}, \mathrm{Ni}, \mathrm{Cd}$ and $\mathrm{Cr}$ because the site is located next to an industrial estate and these metals are commonly used in textile dyes, electroplating, galvanizing, battery manufacture, and plastic fabrication. The pattern of total metal concentrations in the sediment samples was in the decreasing order as: $\mathrm{Zn}>$ $\mathrm{Cu}>\mathrm{Pb}>\mathrm{Ni}>\mathrm{Cd}$.

\section{B. Assessment of Sediment Contamination According to Sediment Quality Guidelines}

Sediments from the sampling sites were assessed and categorised into different pollution levels based on the SQG of US EPA (Table IV). The contamination level of $\mathrm{Cu}$ and $\mathrm{Zn}$ in the sediments ranged between non-polluted, moderately polluted and heavily polluted. Sites 1,3 and 5 were moderately polluted with $\mathrm{Cu}$ and Sites 2, 3 and 5 were heavily polluted with $\mathrm{Zn}$ at. Lead and $\mathrm{Ni}$ in the sediments were classified between non-polluted and moderately polluted, Lead was non - polluted at sites 1,2, 3, 4 and 6 and moderately polluted at Site 5 . Ni was classified as non polluted at sites 1, 4 and 6 and moderately polluted at sites 2, 3 and 6, among the sampling sites and only Site 5 was 
moderately polluted with $\mathrm{Pb}$ while the remaining sampling sites were rated as non-polluted with $\mathrm{Pb}$. The mean concentration of $\mathrm{Ni}$ showed $50 \%$ of the sites were non-polluted and the remaining halves were rated as moderately polluted. The contamination level of $\mathrm{Cd}$ indicated that none of the sampling site was found heavily polluted with Cd.

\section{Assessment of Contamination Factor (Cif) and Degree of Contamination $(\mathrm{Cd})$ in the Surface Sediments}

The determination of contamination factor of heavy metals is an important aspect that indicates degree of risk of heavy metals to environment in relation with its retention time [33]. The contamination factors of heavy metals in the surface sediments based on average shale were presented in Fig. 2 a) and $2 \mathrm{~b}$ ). The contamination factors of $\mathrm{Cd}$ were observed highest at all the sampling sites except at sampling site 2, were Cif of $\mathrm{Zn}$ was highest which correlated with highest concentration of $\mathrm{Zn}$ at the sampling site. A high contamination factor of heavy metal shows low retention time and high risk to the environment [33]. Previous studies in the west coast of peninsular Malaysia have shown elevated levels of $\mathrm{Cd}$ and $\mathrm{Zn}$ in the coastal areas adjacent to industrial estates and urban areas [34]-[36] and ports in the area [17], [18], [36] that might account for high CF of these metals.

The Cif values calculated indicated that all sites were low contaminated with $\mathrm{Cu}$ and $\mathrm{Ni}$ except Site 2 which was moderately contaminated with $\mathrm{Cu}$. Considerable contamination of $\mathrm{Zn}$ was observed at Site 2 while Sites 4 and 1 showed low contamination of $\mathrm{Zn}$.

The contamination factor for $\mathrm{Pb}$ and $\mathrm{Cd}$ revealed moderate and considerable contamination respectively at sites 1, 2, 3, 5 and 6. Low and moderate contaminations were observed for $\mathrm{Pb}$ and $\mathrm{Cd}$ respectively at Site 4 . Lead recorded moderate contamination factor at sites $1,2,3,5$ and 6 , and low contamination at Site 4. Cadmium shows a considerable contamination factor at Sites 1, 2, 3, 5 and while Site 4 showed moderate contamination. The values of degree of contamination (CF) were shown in Fig. 2.

The $\mathrm{Cd}$ values were moderate for all the sites except at Site 4 that showed low Cd. High Cd were observed at Sites 2, 5, and 3, which were assumed to be associated with domestic and/ industrial anthropogenic input and high concentration of metals observed at the sampling sites during the study. The highest $\mathrm{Cd}$ was detected at Site 2 . It is therefore very necessary to monitor heavy metals concentration in Sites 2, 5 and 3 .

\section{Assessment of Ecological Impact in the Surface Sediments}

\section{1) Potential ecological risk index (RI)}

Results of potential ecological risk $(E r i)$ of single metal and the potential ecological risk index $(R I)$ of multi-metals were presented in Table V. The Eri for $\mathrm{Cu}, \mathrm{Zn}$, and $\mathrm{Ni}$ at all the Sites were less than 40 . Therefore the risk grades were in low potential ecological risk. The Er $i$ values for $\mathrm{Pb}$ and $\mathrm{Cd}$ were generally above 40 from all Sites except at Site 4 . The studied metals could be ranked by decreasing severity of ecological risk as: $\mathrm{Cd}>\mathrm{Pb}>\mathrm{Cu}>\mathrm{Ni}>\mathrm{Zn}$, and according to the calculated RI, Cd was the most serious polluting metal in the present study.

The potential ecological risk index (RI) accounting for the contamination caused by $\mathrm{Cu}, \mathrm{Zn}, \mathrm{Pb}, \mathrm{Cd}$ and $\mathrm{Ni}$ indicated that Sites 5, 3 and 2 were exposed to moderate potential ecological risk while Sites 1, 6 and 4 were exposed to low potential ecological risk.
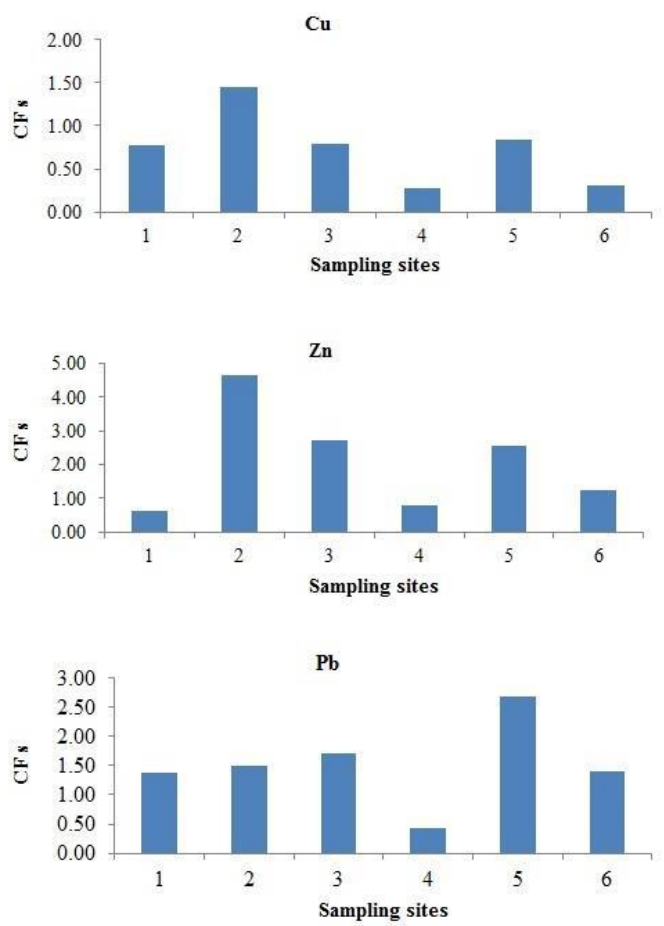

Fig. 2 a). Contamination factor $(\mathrm{CFs})$ of $\mathrm{Cu}, \mathrm{Zn}$ and $\mathrm{Pb}$ in surface sediments of west coast Peninsular Malaysia.
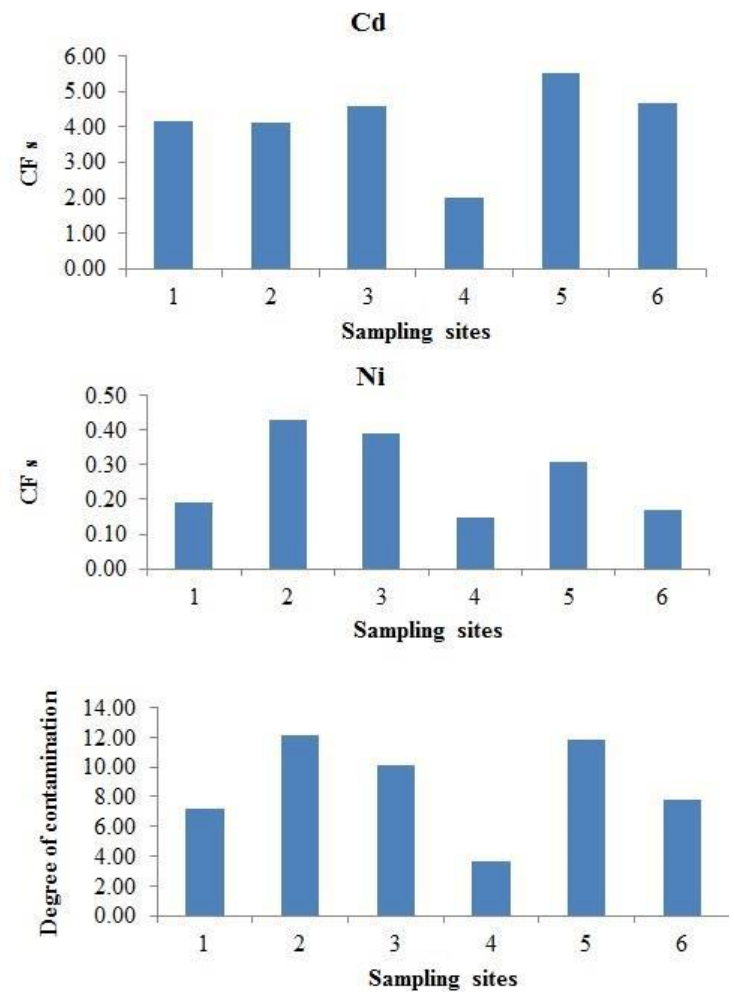

Fig. 2 b). Contamination factors (CFs) of $\mathrm{Cd}$, Ni and degree of contamination in surface sediments of west coast Peninsular Malaysia.

The sampling sites (2,3 and 5) that are associated with high anthropogenic activities shows high RI values mainly resulted from $\mathrm{Pb}$ and $\mathrm{Cd}$. Cadmium and $\mathrm{Pb}$ produced the highest Eri among the studied metals therefore they should be considered 
as the critical metals of concern with regards to ecological hazard in this study.

TABLE V: ER I AND RI HEAVy METALS IN THE SURFACE SEDIMENTS OF WEST COAST PENINSULAR MALAYSIA

\begin{tabular}{ccccccc}
\hline \multirow{2}{*}{$\begin{array}{c}\text { Sampling } \\
\text { site }\end{array}$} & $\mathrm{Cu}$ & $\mathrm{Zn}$ & $\mathrm{Pb}$ & $\mathrm{Cd}$ & $\mathrm{Ni} n$ & \multirow{2}{*}{ SQG-Q } \\
\cline { 2 - 6 } & 0.06 & 0.04 & 0.05 & 0.06 & 0.06 & 0.28 \\
\hline. & 0.12 & 0.33 & 0.05 & 0.06 & 0.14 & 0.70 \\
2. & 0.07 & 0.19 & 0.06 & 0.07 & 0.12 & 0.50 \\
3. & 0.02 & 0.06 & 0.02 & 0.03 & 0.05 & 0.17 \\
4. & 0.07 & 0.18 & 0.10 & 0.08 & 0.10 & 0.52 \\
5. & 0.03 & 0.09 & 0.05 & 0.07 & 0.06 & 0.28 \\
6. & & & & & &
\end{tabular}

Sediment quality guideline quotient (SQG-Q) and probable effect level quotient (PEL-Q) were presented in Table VI. The calculated SQG - Q from all sites falls into impact level category 2; indicating moderate impact potential for observing adverse biological effects a concentration level of metals at which negative effect or impact might be observed on living organism. Higher $\mathrm{SQG}-\mathrm{Q}$ values were found at site with higher PEL - Q values of heavy metals. The highest SQG - Q value was observed at Site 2 which might be attributed to higher anthropogenic activities at this sampling site. A similar result was reported by Caeiro et al. [37] from Sado Estuary sediment were high impact potential for adverse biological effects was observed at hotspots areas found close to anthropogenic sources; at yeast factory and shipyard.

\begin{tabular}{|c|c|c|c|c|c|c|}
\hline \multirow[t]{2}{*}{ Sampling site } & \multicolumn{5}{|c|}{ PEL-Q } & \multirow[t]{2}{*}{$\begin{array}{l}\text { SQG-Q } \\
\text { SQ }\end{array}$} \\
\hline & $\mathrm{Cu}$ & $\mathrm{Zn}$ & $\mathrm{Pb}$ & $\mathrm{Cd}$ & $\mathrm{Ni}$ & \\
\hline 1. & 0.06 & 0.04 & 0.05 & 0.06 & 0.06 & 0.28 \\
\hline 2. & 0.12 & 0.33 & 0.05 & 0.06 & 0.14 & 0.70 \\
\hline 3. & 0.07 & 0.19 & 0.06 & 0.07 & 0.12 & 0.50 \\
\hline 4. & 0.02 & 0.06 & 0.02 & 0.03 & 0.05 & 0.17 \\
\hline 5. & 0.07 & 0.18 & 0.10 & 0.08 & 0.10 & 0.52 \\
\hline 6. & 0.03 & 0.09 & 0.05 & 0.07 & 0.06 & 0.28 \\
\hline
\end{tabular}

\section{E. Assessment of Toxicity Level}
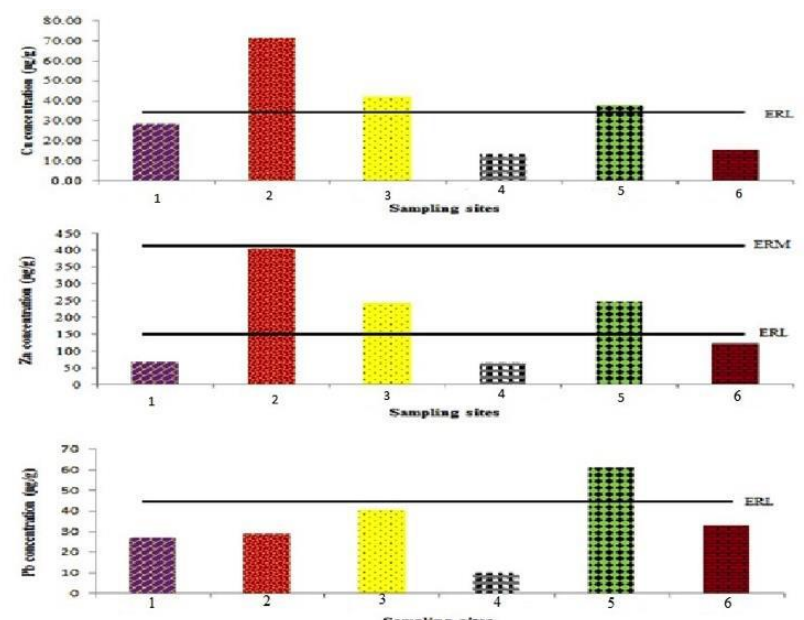

Fig. 3 a). Comparison of $\mathrm{Cu}, \mathrm{Zn}$ and $\mathrm{Pb}(\mu \mathrm{g} / \mathrm{g} \mathrm{d} / \mathrm{w})$ in surface sediments of west coast of Peninsular Malaysia with their respective ERL and ERM values.
Sediment Quality Guidelines (SQG) of effect range-low (ERL) and Effect range-median (ERM) was used to assess the level of toxicity of heavy metals in the surface sediments. Comparison of $\mathrm{Cu}, \mathrm{Zn}, \mathrm{Pb}, \mathrm{Cd}$ and $\mathrm{Ni}$ concentrations $(\mu \mathrm{g} / \mathrm{g}$ $\mathrm{d} / \mathrm{w}$ ) in surface sediments of west coast of Peninsular Malaysia with their respective ERL and ERM values were presented in Fig. 3 a) and b).

The concentrations of $\mathrm{Cu}$ and $\mathrm{Zn}$ at Sites 2, 3 and $4, \mathrm{~Pb}$ at Sites 5, Cd at all the sites (except Site 4) and Ni at Sites 2, 3 and 5 were above their respective ERL values but less than ERM values, this indicates a range within which biological effects could occur occasionally by the present of these metals at the sampling sites. None of the studied metals concentration was found above the ERM values except $\mathrm{Zn}$ at Site 2 indicating the effects of $\mathrm{Zn}$ would be expected to occur frequently on biota at this sampling site.
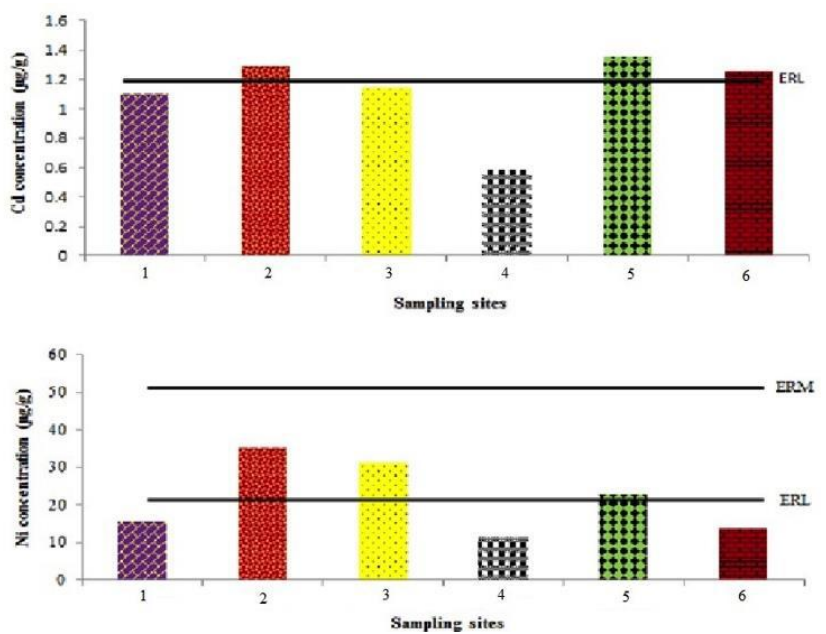

Fig. $3 \mathrm{~b}$ ). Comparison of $\mathrm{Cd}$ and Ni concentrations $(\mu \mathrm{g} / \mathrm{g} \mathrm{d} / \mathrm{w})$ in surface sediments of west coast of Peninsular Malaysia with their respective ERL and ERM values.

\section{CONCLUSION}

In conclusion, the study revealed $\mathrm{Zn}$ and $\mathrm{Cd}$ as metals of great concern. Based on surface sediment assessment for heavy metals contamination the sampling sites were classified within moderate to low levels of contamination which indicates certain level of pollution in some of the study areas. However, there is no special guideline for Malaysian sediment to be followed; therefore continuous assessment is needed to establish the background data for heavy metals in the area, which could be used internationally.

\section{REFERENCES}

[1] A. F. M. Alkarkhi, N. Ismail, A. Ahmed, and A. Easa, "Analysis of heavy metal concentrations in sediments of selected estuaries of Malaysia - A statistical assessment," Environmental Monitoring and Assessment, vol. 153, no 1, pp. 179-185, 2009.

[2] S. A. Al-Shami, C. S. M. Rawi, A. A. Hassan, and S. A. M. Nor, "Distribution of chironomidae (Insecta: Diptera) in polluted rivers of the Juru River Basin, Penang, Malaysia," Journal of Environmental Sciences, vol. 22, no. 11, pp. 1718-1727, 2010.

[3] B. Berthet et al., "Response to metals of the polychaete annelid Hediste diversicolor, a key species in estuarine and coastal sediments," Archives of Environmental Contamination and Toxicology, vol. 4, no. 5, pp. 468-478, 2003.

[4] A. A. Bordalo, W. Nilsumranchit, and K. Chalermwat, "Water quality and uses of the Bangpakong River (Eastern Thailand)," Water Research, vol. 35, pp. 3635-3642. 2001. 
[5] A. Bu-Olayanl, "Trace metals toxicity and bioaccumulation in mudskipper periophthalmus waltoni koumans (Gobiidae: Perciformes)," Turkish Journal of Fisheries and Aquatic Sciences, vol. 8, no. 2, pp. 215-218, 1941.

[6] S. Caeiro, M. H. Costa, and T. B. Ramos, "Assessing heavy metal contamination in sado estuary sediment: An index analysis approach," Ecological Indicators, vol. 5, pp. 151-169, 2005.

[7] L. Hakanson, "An ecological risk index for aquatic pollution control. A sedimentological approach," Water Research, vol. 14, no. 8, pp. 975-1001, 1980

[8] B. T. Hart, "Australian water quality criteria for heavy metals: Australian government publishing service," pp. 229-282, 1982.

[9] M. Ikram, A. Ismail, C. Yap, and A. A. N. Azwady, "Levels of heavy metals $(\mathrm{Zn}, \mathrm{Cu}, \mathrm{Cd}$, and $\mathrm{Pb}$ ) in mudskippers (Periophthalmodon schlosseri) and sediments collected from intertidal areas at Morib and Remis, Peninsular Malaysia," Toxicological and Environmental Chemistry, vol. 92, no. 8, pp. 1471-1486, 2010.

[10] A. Ismail, "Heavy metal concentrations in sediments off Bintulu, Malaysia," Marine Pollution Bulletin, vol. 27, no. 12, pp. 706-707, 1993.

[11] A. Ismail and M. Asmah, "Copper, zinc, lead and cadmium in intertidal molluscs and sediment off Seberang Perai coastline, Malaysia," presented at the Fourth Princess Chulabhorn International Science Congress, Bangkok, Thailand, 1999.

[12] A. Ismail, B. A. G. Idris, and R. I. Sukal, "Distribution of heavy metals in sediment of Port Kelang," in Proc. 12th Anniversary Seminar Malaysian Society of Marine Sciences, Universiti Malaya, Kuala Lumpur, 1989, pp. 279-282.

[13] A. Ismail and R. Ramli, "Trace metals in sediments and molluscs from an estuary receiving pig farms effluent," Environmental Technology, vol. 18 , no. 5, pp. 509-515. 1997

[14] A. Ismail and A. Safahieh, "Copper and Zinc in intertidal surface sediment and Telescopium telescopium from Lukut River, Malaysia," Coastal Marine Science, vol. 29, no. 2, pp. 111-115, 2005.

[15] A. Ismail, C. K. Yap, and F. F. Chan, "Concentrations of $\mathrm{Cd}$, $\mathrm{Cu}$ and $\mathrm{Zn}$ in sediments collected from urban lakes at Kelana Jaya, Peninsular Malaysia," Wetland Science, vol. 2, no. 4, pp. 248-258, 2004.

[16] C. C. M. Ip, X. D. Li, G. Zhang, H. W. Wai, and Y. S. Li, "Trace metal distribution in sediments of the Pearl River Estuary and the surrounding coastal area, South China," Environmental Pollution, vol. 147, pp. 311-323, 2007.

[17] W. Langston, G. Burt, and N. Pope, "Bioavailability of metals in sediments of the Dogger Bank (Central North Sea): A mesocosm study, Estuarine," Coastal and Shelf Science, vol. 48, no. 5, pp. 519-540, 1999.

[18] E. R. Long, L. J. Field, and D. D. MacDonald, "Predicting toxicity in marine sediments with numerical sediment quality guidelines," Environmental Toxicology and Chemistry, vol. 17, no. 4, pp. 714-727, 1998.

[19] E. R. Long et al., "Incidence of adverse biological effects within ranges of chemical concentrations in marine and estuarine sediments," Environmental management, vol. 19, no. 1, pp. 81-97, 1995.

[20] D. D. Macdonald, R. S. Carr, F. D. Calder, E. R. Long, and C. G. Ingersoll, "Development and evaluation of sediment quality guidelines for Florida coastal waters," Ecotoxicology, vol. 5, no. 4, pp. 253-278, 1996.

[21] D. D. MacDonald et al., "Development of an ecosystem-based framework for assessing and managing sediment quality conditions in Tampa Bay, Florida," Tampa Bay Estuary Program, Florida, USA, pp. $1-48,2000$.

[22] G. G. Miller et al., "In vitro toxicity and interactions of environmental contaminants (Arochlor 1254 and mercury) and immunomodulatory agents (lipopolysaccharide and cortisol) on thymocytes from lake trout (Salvelinus namaycush)," Fish \& Shellfish Immunology, vol. 13, no. 1, pp. 11-26, 2002.

[23] B. Morton and G. Blackmore, "South China Sea," Marine Pollution Bulletin, vol. 42, pp. 1236-1263, 2001.

[24] C. Neal, H. P. Jarvie, B. A. Whitton, and J. Gemmell, "The water quality of the River Wear, north-east England," Science of the Total Environment, vol. 251, 252, pp. 153-172, 2000.

[25] K. Nemati, N. K. A. Bakar, and M. R. Abas, "Investigation of heavy metals mobility in shrimp aquaculture sludge - Comparison of two sequential extraction procedures," Microchemical Journal, vol. 91, no. 2, pp. 227-231, 2009.

[26] G. Perin, M. Bonardi, R. Fabris, B. Simoncini, S. Manente, L. Tosi, and S. Scotto, "Heavy metal pollution in central Venice Lagoon bottom sediments: evaluation of the metal bioavailability by geochemical speciation procedure," Environmental Technology, vol. 18, no. 6, pp 593-604, 1997.

[27] A. Rayms-Keller, K. Olson, M. McGaw, C. Oray, J. Carlson, and B. Beaty, "Effect of Heavy Metals on Aedes aegypti (Diptera: Culicidae) Larvae," Ecotoxicology and Environmental Safety, vol. 39, no. 1, pp. 41-47, 1998

[28] S. B. Samani, "The determination of heavy metals in water, suspended materials and sediment from Langat River, Malaysia," Hydrobiologia, vol. 176, pp. 233-238, 1989.

[29] C. E. Seng, P. E. Lim, and T. T. Ang, "Heavy metal concentrations in coastal seawater and sediments off Prai Industrial Estate, Penang, Malaysia," Marine Pollution Bulletin, vol. 18, pp. 611-612, 1987.

[30] P. Szefer, G. P. Glasby, J. Pempkowiak, and R. Kaliszan, "Extraction studies of heavy-metal pollutants in surficial sediments from the southern Baltic Sea off Poland," Chemical Geology, vol. 120, no. 1-2, pp. 111-126, 1995

[31] K. K. Turekian, and K. H. Wedepohl, "Distribution of the elements in some major units of the earth's crust," Geological Society of America Bulletin, vol. 72, no. 2. p. $175,1961$.

[32] A. K. H. Wood, Z. Ahmad, N. A. M. Shazili, R. Yaakob, and R. O. Y Carpenter, "Geochemistry of sediments in Johor Strait between Malaysia and Singapore," Continental Shelf Research, vol. 17, pp. 1207-1228, 1997.

[33] Y.-G. Wu, Y.-N. Xu, J.-H. Zhang, and S.-H. Hu, "Evaluation of ecological risk and primary empirical research on heavy metals in polluted soil over Xiaoqinling gold mining region, Shaanxi, China," Transactions of Nonferrous Metals Society of China, vol. 20, no. 4, pp 688-694, 2010.

[34] C. K. Yap and W. Chew, "A higher bioavailability and contamination of trace metals in Pantai Lido than Sungai Semerak: Evidence from trace metal concentrations in polymesoda expansa and surface sediments," Malaysian Applied Biology, vol. 40, no. 1, pp. 55-59, 2011.

[35] C. K. Yap, M. Rashiq, and F. B. Edward, "Is a mussel processing site a point source of $\mathrm{Zn}$ contamination? Evidence of $\mathrm{Zn}$ remobilization from boiled mussel, perna viridis," Journal of Tropical Agricultural Science, vol. 35, no. 2, pp. 199-207, 2012.

[36] H. Y. Zhou, R. Y. H. Cheung, K. M. Chan, and M. H. Wong, "Metal concentrations in sediments and tilapia collected from inland waters of Hong Kong," Water Research, vol. 32, no. 11, pp. 3331-3340, 1998.

[37] S. Z. Zulkifli, A. Ismail, F. Mohamat-Yusuff, T. Arai, and N. Miyazaki, "Johor strait as a hotspot for trace elements contamination in Peninsular Malaysia," Bulletin of Environmental Contamination and Toxicology, vol. 84, no. 5, pp. 568-573, 2010.

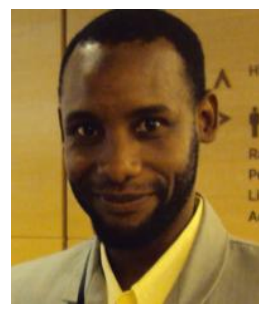

Tijjani Rufa'i Buhari was born in Kano State, Nigeria on July 1, 1968. He started his early primary education from 1975 to 1981 and enrolled into secondary school from 1981 to 1986 in Kano State. He obtained his bachelor of science degree (hon) in applied biology in 1992 from Bayero University Kano, in Kano Nigeria and later the master's degree in ecology in 1998 from the same University. Being a lecturer and ecologist, the global environmental problems motivated him to further his study and research potentials in the areas of ecotoxicology at Universiti Putra Malaysia in 2007 where he graduated in 2012

In 1996 he was employed as a classroom officer with Ministry of Education Kano State, where he joined Kano State Polytechnic from 1997 to 2013 as a lecturer rising to the position of Senior Lecturer. He then joined Northwest University Kano as a lecturer where he is currently the deputy dean Faculty of Sciences and the Head of Department Biological Sciences.

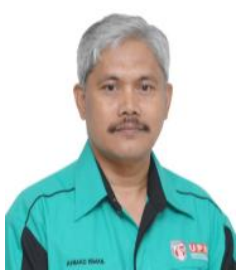

Ahmad Ismail was born in Malaysia. He obtained his bachelor of science degree (hon) in zoology in 1980 and the PhD in ecotoxicology and wild life ecology from University of Sussex in the United Kingdom. He has serve in various capacities as a lecturer with the Department of Biology in the Faculty of Science Universiti Putra Malaysia after his graduation. He is currently a professor of biology, the head of the Department Biology and the president of Academicians of Universiti Putra Malaysia. 